УДК (130.2:572): 177

DOI 10.35423/2078-8142.2021.1.1.10

Н. І. Мокан, аспірантка кафедри філософії, Київський національний університет будівництва і архітектури, м. Kиїв, Україна, e-mail:mokan_n@ukr.net, ORCID: https://orcid.org/0000-0001-7264-1921

I. В. Чорноморденко, доктор філософських наук, професор, завідувач кафедри філософії, Київський національний університет будівництва і архітектури, м. Київ, Україна, e-mail: hmurii@ukr.net, ORCID: https://orcid.org/0000-0002-9204-6342

\title{
ДІАЛОГ КУЛЬТУР ЯК ДІАЛОГ ЦІННОСТЕЙ
}

Статтю присвячено визначенню ролі цінностей у діалозі культур. Цінності, присутні в міжкультурному діалозі, $\epsilon$ важливою складовою культурної ідентичності, здатною об'єднати учасників діалогу. Питання розгляду діалогу культур як діалогу иінностей актуалізується у світлі сучасного глобалізуючого світу та наукових визначень поняття «культура» через иінності. Надзвичайно важливо аналізувати діалог культур, представники яких діють саме з позииії носіїв иінностей, не зосереджуючись на проблемах мовного та етнічного вимірів ідентичності. Зрештою, універсальний характер індивідуальних иінностей має об'єднуючу силу загального прагнення людства до добра, краси, свободи, а отже, сприяє діалогу більше, ніж інші типи спільноти; заохочує до формулювання питань та пошуку відповідей, щуо сприяють співіснуванню в нових умовах. На думку авторів, діалог уникає ситуаиії, коли при взаємодії певна культура воліє виступати єдиним носієм певних моральних істин. Сама ситуачія діалогу встановлює моральні орієнтири, діючи в межах

(C) Мокан Н. I., 2021

(C) Чорноморденко I. В., 2021 
яких учасники діалогу реалізують принципи рівності, відкритості, відповідальності, ненасильства, толерантності, співучасті. Морально-етичні виміри діалогу не допомагають вирішити проблеми культурного співіснування назавжди. Культурні тенденції трансформуються під впливом змін культурних передумов, дискурсу з усіма сочіальними інститутами та прочесами. Діалог має на меті стати місием виникнення відносин, які грунтуються на загальнолюдських, надкультурних моральноетичних принципах, щзо мають силу глобального об'єднання людей. Поряд з ичм у статті зазначається, щуо деякі визначення поняття «культура» розкривають иіннісне ядро самого розуміння феномена культури. Слід розуміти: цінності не є чимось відчуженим від буття, щзо накопичується в процесі людського розвитку. Історична ретроспектива демонструє нам, щзо ичінності активно взаємодіють, «перевіряються на міиність», трансформуються за допомогою діалогу $i$, таким чином, сстановлять основу культури.

Ключові слова: міжкультурний діалог, універсальні цінності, культурні изіності, аксіологія, культура, ідентичність, мова, традииї, толерантність.

Діалог посідає місце важливого методологічного принципу багатьох гуманітарних наук. Природою гуманітарного пізнання стає його діалогічність, яка у своєму узагальненому значенні вказує на пошук істини, або хоча б наближення до неї, внаслідок обміну сенсами під час комунікативного акту. Як предмет та метод багатьох когнітивних практик діалог стає важливим полем досліджень у сфері гуманітарних наук. Із позиції філософії культури діалог розглядається як фундаментальний метод пізнання культури, принцип іiі розвитку та збереження.

Якщо культура постає не лише місцем, де народжуються сенси, а й простором, в якому ними обмінюються, то діалог розкривається як найпродуктивніший спосіб такого обміну. Саме завдяки діалогу культура пізнає себе через іншу, а значущі явища в одній породжують відповідні феномени в іншій - це, своєю чергою, зумовлює наявність спільного культурного буття. Шлях до спільності в діалозі лежить через розрізнення на «своє» та «інше», порівняння, яке уможливлює життя самої культури. Якщо припустити, що учасниками діалогу завжди постають суб’єкти як 140

H.Skovoroda Institute of Philosophy of the NAS of Ukraine 
носії культури, а кожній культурі притаманна власна ціннісна шкала, то доцільно говорити і про діалог 3 позиції порівняння різних ціннісних систем.

Дослідники, які займались проблемами міжкультурних взаємодій, визначали діалог як сутнісну складову міжкультурної комунікації. Започаткування та розвиток теорій діалогу уможливили дослідження культури як події зустрічі «Я» і «Ти» та як взаємини з «Іншим» у працях М. Бубера, М. Бахтіна, К. Ясперса, О. Розенштока-Хюсі, Е. Левінаса, П. Рікера. Суть діалогічного дослідження, як такого, де «друга» сторона діалогу, культура минулого або просто культура «інша» виступають «на рівних», а не лише як матеріал, що підлягає науковій обробці, розкриває сучасна вітчизняна дослідниця С. Гатальська. О. Астаф’єва виокремлює шість груп трактувань поняття міжкультурний діалог. Окремі його аспекти описуються також у дослідженнях: В. Аксьонової, Л. Абракова, Н. Бачко, Т. Бесараб, О. Бучковської, I. Гусленко, Л. Дротянко, Н. Кокшарова, В. Межуєва, О. Назаренко, В. Федь, С. Шевчук. Загальний огляд підходів до вивчення міжкультурного діалогу та взаємодії культур здійснила О. Мітькіна. Аксіологічні аспекти діалогу культур досі залишаються недостатньо дослідженими.

Теоретико-методологічне обгрунтування культурних цінностей можна знайти у працях В. Віндельбанда, Г. Ріккерта, А. Мюллера, М. Шелера, Н. Гартмана, Т. Лапіна. Релігійну природу та екзистенційну сутність цінностей відзначали М. Бердяєв, I. Ільїн, Н. Лоський, П. Флоренський, Е. Гуссерль, Г. Марсель, М. Каган, М. Докучаєв. Принципи аксіологічного аналізу міжкультурних взаємодій викладені у працях В. Бакшутова, В. Большакова, Г. Вижлєцова, Е. Голла, О. Дробницького, Д. Трагера, У. Ханас. Ці автори зробили вагомий внесок у розвиток теорії культурних цінностей та обгрунтували їхню значущість для гуманітарних наук.

Досі об' єктом досліджень діалогу культур ставала переважно природа інтерсуб' єктних зв'язків та самі відношення: «Я - Ти», «Я»- «Інший», «Свій»- «Чужий», в яких аксіологічна складова не повинна була впливати на долю міжкультурних взаємодій. Однак суб'єкт, який, взаємодіючи 3 Іншим, пізнає культуру, першою 
чергою робить це через засвоєння певної системи культурних цінностей. При цьому сприйняття іншої культури через систему цінностей власної культури радше свідчить про незрілість останньої. Нездатність до сприйняття цінностей інших культур дедалі частіше призводить до виникнення вороже налаштованих національних рухів. У цьому ключі, важливим $є$ дослідження діалогу культур 3 точки зору впливу універсальних цінностей на його перебіг, значення морально-етичних та гносеологічних цінностей діалогічних взаємодій, виявлення природи цінностей культури.

Багатогранність міжкультурного діалогу засвідчує значна кількість груп визначення самого поняття та концептуальних підходів до його дослідження. Наприкінці минулого століття поняття міжкультурного діалогу стає чи не головним об'єктом філософського осмислення і набуває різних дефініцій. Узагальнене його визначення зводиться до обгрунтування діалогу як складного творчого процесу взаємодії між людьми, які $\epsilon$ носіями різних культур та різних систем цінностей, передумовою якого постає взаємна відкритість. При цьому утворюється своєрідний комунікативний стан «між», коли одночасно відбувається порівняння та обмін смислами. «Діалог культур - це спосіб людського спілкування, це поєднання різних смислів (понять, символів) культури, де формується орієнтація розуму на взаєморозуміння» [1, с. 328]. У діалозі культур таке поєднання смислів відбувається між суб'єктами - представниками різних ідентичностей. Своєю чергою, кожна ідентичність передбачає властиву їй систему цінностей, мову, усталені зразки поведінки. Як саме три основні складові ідентичності здатні впливати на діалог, i якого характеру набуває цей вплив? Дотепер питання лишається недостатньо розкритим у наукових колах. У даному дослідженні нас цікавить саме третя головна складова ідентичності, а саме система цінностей.

Щодо зразків поведінки, то саме завдяки ним якісно відрізняються більшість культур. Історично встановлені норми, традиції, символічний ряд, схеми діяльності, механізми самодисципліни мають важливе значення для кожної конкретної 
культури та вирізняють іï 3-поміж інших. Різність культур $\epsilon$ передумовою та запорукою розбіжностей у позиціях кожної зі сторін діалогу (за рахунок цього власне і зберігається ідентичність певної культури). Але саме через пізнання інших культур здійснюється самоусвідомлення культури. «Одна культура дивиться в іншу не для того, щоб рахуватись з нею, знайти себе в ній, а для того, щоб відрізняти себе від неї, протистояти їй, глибше усвідомити власну ідентичність» [2, с. 66]. Різність культур та неповторна самобутність кожної з них не дає можливості звести діалог до універсального синтезу. Діалог «приречений» постійно долати проблему культурної нерівності та претензії культур на винятковість.

Мовну складову міжкультурного діалогу також можна зарахувати до роз'єднальної. Чимало дослідників неодноразово відзначали комунікативні лакуни між культурами, які актуалізують ситуацію непорозуміння між ними. Розбіжності в комунікативних сценаріях різних культур мають систематичний характер i пояснюються відмінностями у культурному досвіді, «ресурсах» іiі смислотворчого апарату, динаміці мовленнєвого акту, вживаннях специфічних лінгвістичних форм, виборі комунікативної стратегії тощо. Комунікативні лакуни між культурами можуть бути заповнені шляхом залучення процедур трансляції іншокультурних смислів - перекладів, що можуть існувати на різних рівнях. Діалог,

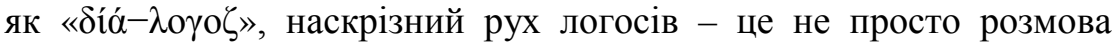
різними мовами, а спілкування зі спробою перекладу, що спрямоване на взаєморозуміння.

Цінності, в силу своєї універсальної природи, на відмінну від зразків поведінки і мови мають більш об'єднуючі властивості для діалогу. Крім того, цінності можна створити та пізнати через діалог, що відзначають представники однієї з філософських шкіл. У 20-ті роки минулого століття на противагу філософії трансценденталізму виникає школа діалогічної філософіі. Діяльність обох шкіл не обмежувалася суто теоретичною розробкою загальнофілософських питань, але й знайшла своє вираження у двох філософських концепціях культури. Якщо філософи трансценденталізму (П. Наторп, Г. Віндельбанд, Г. Рікерт) розгорнули аксіологічний підхід до культури, пояснюючи культуру через 
природу та сутність цінностей, то філософи діалогу (М. Бубер, М. Бахтін, В. Біблер, О. Розеншток-Хюсі, К. Ясперс, Е. Левінас, П. Рікер) усвідомлювали буття культури як діалогічний розвиток, який сам $€$ умовою для пізнання, освоєння та примноження цінностей.

Глобалізаційні процеси, що послуговуються кількома міжнародними мовами i сприяють розмиванню державних кордонів, призвели до того, щзо культури дедалі частіше почали визначати себе не мовними та етнічними ідентичностями, а цінностями. Мова чи колір шкіри перестають мати значення для спільного проживання, значно важливішими стають світоглядні орієнтири, ціннісні уявлення та пріоритети. Ще К. Ясперс наголошував, що «істинна цінність людини полягає не в роді чи типі, до якого вона наближається, а в історично одиничній людині, яка не може бути замінена і заміщена» [3, с. 454]. Історичність, як справжня сутність людини, виявляється в екзистенції. Екзистенціювати означає поставати собою в конкретно історичній унікальності, виходити за межі повсякденного мислення i соціально організованого досвіду, відчувати всередині себе свободу як «екзистенційний поклик». Людина є унікальною у своїй екзистенції, найбільшою цінністю якої $є$ свобода. Найповніше екзистенція проявляється в комунікації між людьми, які, потенційно маючи таку свободу, щиро відкриваються одне одному. Більше того, на його думку, свобода не може існувати сама по собі, «ізольовано», тільки спільно люди здобувають свободу. Неважливо 3 позиції якої культури здійснюється комунікація, значно важливіше сприймати співрозмовника як вищу цінність, яка дасть можливість здобути власну свободу, адже свобода одного індивіда слугує умовою свободи інших. До того ж, свободі філософ надає абсолютного значення, оскільки вона дає змогу вийти за межі іманентного світу у світ трансцендентного, тобто знайти ті абсолютні основи, на які людина має орієнтуватись у своєму житті. Знаки трансцендентного, які можна спостерігати у нашому світі у вигляді шифрів, відкриваються завдяки комунікації, заснованій на свободі. Завдяки абсолютним цінностям К. Ясперс пояснює власну екзистенцію, що сприяє виходу з духовної кризи. Повною мірою 
екзистенція проявляється під час комунікації через відкритий діалог із «собі подібними», існування яких $\epsilon$, у цьому сенсі, справжньою цінністю.

На аксіологічній компоненті діалогу наголошують і інші філософи-діалогісти. Вони пропонують ідентифікувати співрозмовника не через його належність до конкретної культури, а виходячи 3 його духовної природи, визначеної абсолютними цінностями. Зокрема, М. Бубер вбачає у діалозі «Я-Ти» відносини, у яких співрозмовник має справу 3 ціннісною i духовною природою людини. М. Бахтін зазначав, що це відносини якісно різних особистостей, здатних до сприйняття Іншого як самоцінної особистості. Для Е. Левінаса Інший стає єдиною можливістю існування Я як свободи та тим, хто звільняє його від обтяженості собою.

Універсальні цінності мають об'єднальний характер, що сприяє діалогу більше, ніж будь-яка культурна спільність. Це підтверджується і тим, що діалог найбільше актуалізується там, де перетинаються абсолютно різні культури. При цьому, він не зводиться до їх взаємної терпимості, а передбачає певний особливий зв'язок між ними - коли культури «об'єднані загальністю кінцевих життєвих цілей» [2, с. 66], коли вони однаково розуміють істину і справедливість, ототожнюючи їх із золотим правилом моралі. А. Гусєйнов наводить приклад Махатма Ганді, який дійшов висновку, що всі релігії $є$ єдиними у своїх внутрішніх принципах і різними у зовнішніх проявах. У цілому, прагнучи удосконалення, людство орієнтується на ідеал ненасилля, якому належить вагома роль регулятора поведінки, спрямованої на збереження життя планети, взаємопорозуміння та злагоду між людьми. Загальнолюдське означає спільне для всіх людей, воно не залежить від їхніх національних чи культурних відмінностей. Це те, що сприяє встановленню соціальних зв'язків, уможливлює взаємний діалог і взаєморозуміння. Головне діалогічне значення загальнолюдського полягає в тому, що воно грунтується на визнанні цінностей не лише «свого», а й «чужого». Однак виокремлення загальнолюдських цінностей є конкретно-історично зумовленим. Крім того, складним залишається питання визначення граничної основи обгрунтування цінностей загальнозначущих 
культур. Також слід пам'ятати, що загальне не варто утверджувати як найзмістовнішу норму, а лише як «відкриту умову для виявлення особливого» $[4$, с. 6$]$.

Сьогодні дедалі частіше ми стаємо свідками та учасниками ситуацій, що демонструють недосконалість глобалізаційних проектів. Взяти хоча б останню світову економічну кризу, спричинену раптовою неспроможністю однієї країни (Китаю) повною мірою брати участь у світовому економічному житті; чи кризу мультикультуралізму, про яку свідчать дедалі частіші спалахи насильства між титульними націями та мігрантами. Зважаючи на наявність такого типу обставин, діалог може слугувати найефективнішим методом примирення, взаємного збагачення, розвитку культур.

Сучасні проблеми глобалізації та пов'язані з ними кризові явища стають точкою біфуркації нового світового порядку, здійснення якого уможливлюється шляхом ефективної взаємодії культур методом ціннісного діалогу. Оскільки культури дедалі більше прагнуть до утвердження своєї унікальності через декларування себе носіями моральних істин, то на перший план виступають певні морально-етичні принципи, щуо стають умовою можливості діалогу між ними. У різних куточках світу тривають колишні та виникають нові конфронтації між культурами. Ціннісний діалог - ефективний спосіб комунікації, спрямований на постійний пошук ціннісних сенсів 3 метою уможливлення взаємодії, виявлення нового, знищення стереотипності та уникнення конфліктності. Це не означає, що ціннісний діалог культур повинен робити своїм предметом їх ціннісноепістемологічний статус, систему цінностей, ментальність, архетипи, систему символів чи знаків, культурні надбання. Скоріше навпаки, питання такого типу нерідко визначаються дослідниками як такі, що роз'єднують, викликають конфронтацію, підносять чи занижують статус певної культури в очах іншої, підкреслюють їхню фактичну нерівність; $€$ причинами космополітизму, шовінізму чи утилітарного ставлення однієї культури до іншої (коли одна культура нав'язує свою систему цінностей, значень та норм іншій культурі, що унеможливлює 
повноцінне взаємне збагачення та взаємний розвиток).

Культурний плюралізм у поєднанні 3 економічними, політичними, екологічними, технологічними, демографічними викликами сучасності потребують попереднього узгодження методів міжкультурних взаємодій. Діалог як спосіб комунікації регулюється низкою морально-етичних принципів: толерантності, взаємоповаги, рівності ціннісних систем окремих культур, паритетності суб'єктів - учасників діалогу. Структура діалогу, крім присутності двох суб'єктів та просторово-часових параметрів, охоплює сам процес, що передбачає наявність ціннісних сенсів, орієнтованих на врегулювання та розширення діалогу. Саме ціннісні сенси створюють фундамент для взаємодії всього людства. О. Мітькіна доходить висновку: «Міжкультурний діалог $\epsilon$ могутнім інструментом посередництва та примирення, єдності, соціальної згуртованості та взаєморозуміння. При цьому свобода вибору, свобода висловлювання, рівність, толерантність та взаємоповага є ключовими елементами міжкультурного діалогу» [5, c. 334].

Сам феномен діалогічності міжкультурної взаємодії $\epsilon$ цінністю, оскільки спостерігається здатність людей у процесі діалогу бути разом, залишаючись при цьому в межах своєї ідентичності. Діалог - це місце, де уможливлюється творення універсальних, надкультурних взаємостосунків, які надалі можуть стати основою глобального об'єднання людей. Багато світових конфліктів можна вирішити за допомогою діалогу та його головних ціннісних орієнтацій - етики і моралі. У своєму дисертаційному дослідженні «Етичні аспекти діалогічних концепцій культури» О. Назаренко підкреслює, що звернення до діалогу у філософській площині зумовлене численними сподіваннями на запровадження етичного виміру у філософській теорії. Сучасна філософія діалогу вирішує світові проблеми за допомогою етики ненасилля та відповідальності. Авторка досліджує головні етичні аспекти феномена діалогу: відповідальність, рівність, толерантність, ненасилля, співучасть, відкритість відносно Іншого, ідея рівноцінності культур та принцип гостинності, що покладені у систему відносин «ЯІнший»». 


\section{Етична орієнтація діалогу $є$ певним стандартом, що} визначається філософською теорією діалогу у вигляді цінніснозаданої єдності, яка характеризує людство з точки зору єдності ментальних установок, життєвих зразків, суспільних звичок. Тобто, діалог покликаний стати місцем, де виникають універсальні, надкультурні взаємостосунки, зміцнені моральноетичними принципами, що мають силу глобального об'єднання людей. Однак подібні ціннісні орієнтири діалогу не є сталими такими, що допомагають назавжди вирішити проблеми співіснування культур, визначити культурну ідентичність іiі носіїв. Це засвідчує, зокрема, виникнення нових рухів етнічних меншин у розвинутих країнах. Можна з упевненістю сказати, що встановлені морально-етичні цінності діалогу схильні до трансформації під впливом культурних передумов. Тобто, морально-етичні цінності діалогу повинні вступати у теоретичний дискурс 3 усіма культурами та їх суспільними інститутами, серед яких право, влада, громадянське суспільство, масові рухи, регіональні конфлікти. «Замість незалежного й відкритого пошуку культурних передумов, що грунтуються, зазвичай, на знанні культури, нам пропонують задану й немовби об'єктивно визначену систему цінностей. Дискурс культури у кращому разі набуває пропедевтичної цінності культурологічних студій або вироджується в пусту балаканину, а в гіршому випадку перетворюється на ідеологію, тобто відкриває шлях до культурного насильництва. А це завжди містить у собі небезпеку появи людей, партій, влади, які намагатимуться довести це за допомогою насильства й тортур» [4, с. 11].

Ще однією цінністю діалогу, крім морально-етичної складової, $є$ його гносеологічний потенціал. Культура набуває здатності до внутрішньої рефлексії своєї специфіки, лише розглядаючи себе крізь призму іншої культури. М. Бахтін підкреслює, що «культура тільки в очах іншої культури розкриває себе повніше й глибше. Певний смисл розкриває свої глибини, зустрівшись і зіткнувшись 3 іншим, чужим змістом, між ними починається ніби діалог, який долає замкнутість і однобічність цих смислів, цих культур. Під час такої діалогічної зустрічі двох 
культур вони не зливаються і не змішуються, але вони взаємозбагачуються» [6, с. 354]. Хоч таке взаємозбагачення відбувається на різних рівнях, в одному випадку інонаціональні твори культури сприймаються як інонаціональні і не входять у систему духовного світу особистості. В іншому випадку взаємозбагачення не обмежується простим ознайомленням 3 творами інших культур, відбувається створення чогось нового на основі пізнання свого через інше. Діалог дає змогу особистостям не лише залучитись до вітчизняних і національних цінностей, а й пізнати інші культури, самовизначитись у світі культури та удосконалювати себе як суб'єкта культури.

Звернутись до цінностей спонукає i саме визначення культури, що, першою чергою, пояснюється як феномен, який поєднує в собі сукупність матеріальних та духовних цінностей, здатних стати основою для об'єднання людей. Під поняттям «культура» розуміють: сукупність об'єктів, пов'язаних із загальнозначущими цінностями, що плекаються заради цих цінностей (Г. Ріккерт); спосіб та метод ціннісного освоєння дійсності (А. Ефендієв); цінності, що йдуть із глибини індивідуального і соціального життя (Г. Вижлєцова); метацінність (Ю. Солонін). Спираючись на такі положення Т. Лапіна визначила «поняття культури як досвід виробництва та засвоєння цінностей людьми» [7, с. 35]. Із самого визначення поняття культури через иінності постає потреба говорити про діалог культур як діалог иінностей.

Аксіологія культури, яка $є$ ціннісною теорією культури i одночасно філософським вченням про цінності, виникає на початку XX століття - у період світових і громадянських війн, революцій, катаклізмів, ціннісна проблематика набуває свого самостійного значення, отримує своє місце та ім'я у системі філософського знання. Три періоди іiі історії, а саме - класичний (1890-1930), некласичний (1930-1970), постнекласичний (19702010), дають різні пояснення сутності цінностей культури. Від онтологічних учень про цінності, які створюють передумови для розвитку ціннісної філософії культури, до виникнення різних аксіологічних концепцій, в яких створюється та розвивається поняття «аксіологія культури», що визначає сутність культури в 
здатності до створення, зберігання, освоєння, примноження цінностей. Історія розвитку аксіології говорить нам про різні джерела походження цінностей. Останні визначалися як трансцендентальні, релігійні, суб'єктивістські, екзистенційні; отримували різну ієрархічну систему впорядкування та класифікацію. Незмінною завжди залишалась міжсуб'єктивна природа цінностей, що виражається у здатності вибудовування стосунків між особистостями, спільнотами, суспільствами, виходячи $з$ принципу самоцінності суб'єктів діалогу. Діалогічна форма таких відносин вказує на динамічний характер реального буття цінностей, а не на їхнє існування у вигляді суворо побудованих ієрархічних систем.

Окремі визначення поняття «культура» демонструють нам ціннісне ядро самого розуміння феномена культури. У них наголошується, що культуру слід розглядати не лише як здатність до накопичення певних цінностей у процесі еволюції людства, але і як активне їх здійснення в бутті людини. Культурні цінності не $\epsilon$ чимось застиглим у надлюдському просторі, відчуженим від людського буття, де діяльність виступає своєрідним рухом цінностей у світі. Водночас, коли ми говоримо діяльність, то маємо на увазі їі мисленнєві, творчі, духовні, практичні та комунікативні форми. Якщо у процесі мисленнєвої, творчої та духовної діяльності цінності постають ідейно, у практичній діяльності втілюються матеріально, то в комунікативній - накопичуються, пізнаються, розкриваючи свою сутність перед «лицем» одна одної, взаємодіють. Культурні цінності у суспільному бутті створюються і зберігаються у вигляді сукупності знаків та текстів. Це, своєю чергою, створює особливе комунікативне поле, що і становить світоглядну основу буття культури. Знаки існують для регулювання людської поведінки. Культурні цінності - особливий знаково-семіотичний корпус цивілізації.

Таким чином, потреба пошуку нових проектів співіснування культур неможлива сьогодні без діалогу між цими культурами. Філософія культури розглядає міжкультурний діалог за аналогією 3 особистісним, де людина постає носієм певної культури, постає як слово, повідомлення, спрямоване на адресата - «Ти», «Іншого», 
«Чужого». Бути носієм культури означає співвідносити себе зі спільнотою, що має не лише спільну мову, звичаї, традиції, а й спільні духовні та матеріальні цінності. Діалог 3 позиції носія певної мови та культурних зразків поведінки хоч і становить загрозу розбіжності, однак сприяє збереженню культурних відмінностей шляхом кращого розуміння своєї культури через пізнання іншої, зокрема й через діалогічне спілкування. Інша справа з цінностями, роль яких не така вже й однозначна.

Діалог відбувається в умовах швидкої перебудови економічних та соціально-політичних структур, загальних викликів, зростання внутрішньої різноманітності культур, що спонукає до формування i поширення морально-світоглядних цінностей, які відповідатимуть новим потребам. Цінності дедалі більше стають предметом діалогу, переосмислюються ціннісні орієнтири окремої культури та всього людства. Діалог культур постає як діалог цінностей, що засвідчують такі спостереження. По-перше, культури дедалі більше почали визначати себе не мовними та етнічними ідентичностями, а цінностями. 3 одного боку, цінності спонукають до діалогу з позиції роз'єднання в сенсі порівняння, оцінювання, протиставлення цінностей своєї культури 3 іншою. Основою такого роз'єднання є ціннісна відмінність культур, системи цінностей, які становлять ядро певної культури. 3 іншого боку, цінності мають об'єднуючу силу загального прагнення людства до добра, блага, краси, свободи, що спонукає до постановки спільних запитань та пошуків відповідей, які сприяють спільному проживанню в нових умовах. По-друге, в процесі діалогу встановлюється ряд морально-етичних принципів: рівність, толерантність, взаємоповага, відповідальність, що уможливлюють взаємодії культур, що дедалі більше прагнуть підкреслити свою унікальність саме як носії моральних істин. Потретє, слід наголосити на ціннісній природі самого діалогу, що дає культурам можливість пізнавати самих себе через пізнання інших. По-четверте, визначення поняття культури через цінності, вказує на необхідність дослідження саме аксіологічного аспекту діалогу культур. Процес діалогу розкриває цінності через міжсуб'єктивні зв'язки, тим самим вказуючи на їх динамічну природу та здатність до накопичення у вигляді знаків і текстів, що і стають тими 
словами та повідомленнями, спрямованими на адресата. Наші подальші дослідження діалогу культур будуть спрямовані на визначення чинників, які визначають цінності діалогу культур, пояснюють значення загальнолюдських та культурних цінностей у процесі діалогу.

\section{ЛІТЕРАТУРА}

1. Гатальська С. М. Філософія культури. Київ : Либідь, 2005. 328 с.

2. Гусейнов А. А. Диалог культур: возможности и пределы. Диалог культур и партнерство цивилизаций. VIII Международные научные Лихачёвские чтения. 22-23 мая 2008 г. СПб., 2008. С. 65-70.

3. Ясперс К. Философская вера. Ясперс К. Смысл и назначения истории. Москва : Политиздат, 1991. 527 с.

4. Бистрицький Є. Конфлікт культур і філософія толерантності. Ідея культури: виклики сучасної цивілізації. К., 2003. С. 3-11; 77-96.

5. Мітькіна О. Огляд підходів до вивчення міжкультурного діалогу і процесів взаємодії культур. Міжнародні зв 'язки Украӥни: наукові пошуки $i$ знахідки. 2013. С. 324-336.

6. Бахтин М. М. Эстетика словесного творчества. Москва: Искусство, 1986. 445 с.

7. Лапина Т. Аксиология культуры. Вестник культурологии. Москва: Федеральное государственное бюджетное учреждение науки Институт научной информации по общественным наукам Российской академии наук, 2008. С. 34-44.

8. Енциклопедія сучасної України. URL: http://esu.com.ua/search_ articles.php?id=51489

\section{REFERENCES}

Bakhtin, M. M. (1986). Aesthetics of verbal creativity. Moscow. Art. [In Russian].

Bystritsky, E. (2003). The idea of culture: the challenges of modern civilization. [In Ukrainian].

Encyclopedia of modern Ukraine. Retrieved from http://esu.com.ua/ search_articles.php?id=51489 [In Ukrainian].

Gatalska, S. (2005). Philosophy of culture. Kyiv: Libid. [In Ukrainian]. 
Guseinov, A. A. (2008). Intercultural Dialogue: Opportunities and Limits [Paper presentation]. In Dialogue of Cultures and Partnership of Civilizations. VIII International scientific Likhachev readings. St. Petersburg, May, 65-70. [In Russian].

Jaspers, K. (1991). The meaning and purpose of history. Moscow: Politizdat. [In Russian].

Lapina, T. (2008). Axiology of culture. Bulletin of cultural studies, 34-44. [In Russian].

Mitkina, O. (2013). Review of approaches to the study of intercultural dialogue and processes of interaction of cultures. In International Relations of Ukraine: scientific research and discoveries (pp. 324-336). [In Ukrainian].

\title{
Natalia Mokan
}

Post-Graduate Student of the Department of Philosophy, Kyiv National University of Construction and Architecture; Kyiv, Ukraine; e-mail: mokan_n@ukr.net; ORCID: https://orcid.org/0000-0001-7264-1921

\section{Ivan Chornomordenko}

Doctor of Philosophical Sciences, Professor, Head of the Department of Philosophy, Kyiv National University of Construction and Architecture; Kyiv, Ukraine; e-mail: hmurii@ukr.net; ORCID: https://orcid.org/0000-0002-92046342

\section{Dialogue of cultures as a dialogue of values}

\begin{abstract}
The article is devoted to defining the role of values in the dialogue of cultures. The values present in intercultural dialogue are an important component of cultural identity, able to unite the participants in the dialogue. The question of considering the dialogue of cultures as a dialogue of values is actualized in the light of the modern globalizing world and scientific definitions of the concept of «culture» through values. It is extremely important to analyze the dialogue of cultures, the participants of which act precisely from the position of bearers of values, and not focusing on the problems of linguistic and ethnic dimension of identity. After all, the universal nature of individual values has the unifying force of the common aspiration of mankind to good, beauty, freedom, and
\end{abstract}


therefore promotes dialogue more than other types of community; encourages the formulation of questions and the search for answers that facilitate coexistence in new conditions. According to the author, dialogue avoids the situation when, when interacting, a particular culture prefers to act as the sole bearer of certain moral truths. The very situation of the dialogue sets moral guidelines, acting within which the participants in the dialogue implement the principles of equality, openness, responsibility, non-violence, tolerance, complicity. The moral and ethical dimensions of dialogue are not helping to solve the problems of cultural coexistence forever. The culturals tend to transform under the influence of changes in cultural preconditions, discourse with all social institutions and processes. Dialogue is intended to become a place of emergence of relationships that are built on universal, supracultural moral and ethical principles, which have the force of global unification of people. Along with this, the article notes that some definitions of the concept of "culture» reveal the value core of the very understanding of the phenomenon of culture. It should be understood that values are not something alienated from being, accumulates in the process of human development. Historical retrospective shows us that values actively interact, are tested for strength, are transformed through dialogue, and thus form the basis of culture.

Keywords: intercultural dialogue, universal values, cultural values, axiology, culture, identity, language, traditions, tolerance. 